\title{
ASPEK KEADILAN DALAM KONTRAK BISNIS DI INDONESIA (Kajian pada Perjanjian Waralaba )
}

\author{
Ery Agus Priyono ${ }^{1}$ \\ Fakultas Hukum Universitas Diponegoro \\ J I. Prof. Soedarto SH, Tembalang, Semarang, 50275 \\ eap_fh_undip@yahoo.com
}

\begin{abstract}
The agreement, the essence is agreement, is characterized by a meeting of mind, the parties to achieve an agreed goal in order to provide maximum benefit for the parties. Agreements like a legal document should meet at least three elements as stated by Gustav Radbruch, namely justice, legal benefits, and certainty, but the fact is that the legal certainty aspect (in principle Pacta Sunservanda) is most prominent even sometimes ignoring justice. This article aims to uncover why this happens, what is the reason and how is the solution. Approach to philosophical normative research is used to analyze contract documents referring to the relevant regulations and the principle of agreement. As a conclusion, there is no justice achievement for the parties, especially the franchisee, because the franchisor's bargaining position is very strong, not balanced when compared to the weak bargaining position of the franchisee. This has an impact on the contents of the contract that is made entirely by the franchisor, which certainly tends to provide the greatest benefit to the franchisor.
\end{abstract}

\section{Keywords: Agreement; Franchise; J ustice; Philosophical Normative.}

\begin{abstract}
ABSTRAKSI
Perjanjian, esensinya adalah kesepakatan, disifati dengan bertemunya kehendak (meeting of mind, mutual assent ) para pihak untuk mencapai suatu tujuan yang telah disepakati guna memberikan kemanfaatan semaksimal mungkin bagi para pihak. Perjanjian layaknya sebuah dokumen hukum sudah sepantasnya memenuhi minimal tiga unsur sebagaimana dikatakan oleh Gustav Radbruch, yakni keadilan, kemanfaatan dan kepastian hukum, akan tetapi faktanya aspek kepastian hukum (dhi asas Pacta Sunservanda) paling menonjol bahkan kadang mengabaikan keadilan.Tulisan ini bertujuan untuk mengungkap mengapa hal tersebut terjadi, apa sebabnya dan bagaiamana solusinya.Pendekatan penelitian normatif filosofis digunakan untuk menganalisis dokumen kontrak mengacu pada peraturan yang terkait dan asas asas perjanjian. Sebagai kesimpulan tidak tercapainya keadilan bagi para pihak khususnya penerima waralaba, dikarenakan posisi tawar pemberi waralaba (franchisor) yang sangat kuat, tidak seimbang jika dibandingkan dengan posisi tawar penerima waralaba (franchisee) yang lemah. Hal ini berimbas pada isi kontrak yang sepenuhnya dibuat oleh pemberi waralaba (franchisor), yang tentunya cenderung memberikan manfaat sebesarbesarnya bagi pemberi waralaba (franchisor).
\end{abstract}

\section{Kata kunci : Perjanjian; Waralaba; Keadilan; Normatif Filosofis.}

\footnotetext{
${ }^{1}$ Dosen Fakultas Hukum Universitas Diponegoro
} 


\section{A. Pendahuluan}

Pengertian perjanjian, sebagaimana diatur dalam Pasal 1313 KUH Perdata adalah Suatu Perbuatan dengan mana satu orang atau lebih mengikatkan dirinya pada satu orang atau lebih lainnya. Abdulkadir Muhammad dalam Ilhamdi bependapat definisi ini sangat umum sehingga tidak bisa menggambarkan esensi yang sebenarnya. Kelemahan yang ada pada definisi tersebut adalah sifatnya yang sepihak, tidak menyebut tujuan, tetapi juga tidak memberi batasan pada kata "pebuatan" yang tentunya sangat luas pemahamannya (Ilhamdi, 2014).

Sebuah perjanjian baik dibuat secara lisan (oral) atau tertulis (written, contract) hendaknya dapat mengekspresikan kehendak para pihak yang bersifat umum menjadi langkahlangkah atau perbuatan yang lebih nyata guna mewujudkan tujuan dibuatnya perjanjian yang telah disepakati sebelumnya (Schwartz \& Scott, 2003).

Perjanjian yang dibuat oleh para pihak baik secara lisan maupun tertulis perlu mengindahkan asas-asas hukum perjanjian, peraturan-peraturan hukum yang terkait dengan perjanjian. Asas-asas itu antara lain yang sangat penting adalah asas kebebasan berkontrak, (freedom of contract, partij autonomie) (Schwartz \& Scott, 2003).
Asas ini menjadi dasar berlakunya asas konsensual, yang asas konsensual ini mendasari berlakunya asas kekuatan mengikat perjanjian (pacta sun servanda) (Priyono, 2015)

Penerapan terhadap asas-asas tersebut di atas khususnya pada tahap pra kontrak (pre contract) maupun umumnya pada tahap kontrak (contract) tidak bisa dilakukan dengan sebebas bebasnya, tetapi dalam bingkai asas itikad baik dan kepatutan (Sepe, 2010). Itikad baik tidak sekedar dilihat secara subyektif (Black, 2017) dalam arti tidak menipu, tidak bohong, tidak jujur, akan tetapi juga secara obyektif. Obyektif dalam arti perjanjian harus dilaksanakan berdasarkan peraturan (Posner, 2001) (buku III KUH Perdata dan PP nomor 42 tahun 2007 tentang Waralaba) serta kesusilaan dan kepatutan (Sepe, 2010). Asas itikad baik di negara-negara penganut common law, pada awalnya merupakan implied contractual obligation (lihat introduction of the Uniform Commercial Code, in the 1960s) dalam perkembangannya menjadi promise sebagaimana di usulkan oleh state legislatures.

Faktanya dalam praktek kegiatan/aktifitas bisnis, perjanjian bisnis (business agreement, business contract) hampir semua dibuat dalam bentuk tertulis. Kecenderungannya perjanjian yang tertulis ini dibuat oleh salah satu pihak yang kuat posisi ekonominya, dalam bentuk perjanjian baku (standard form Contract). Istilah kontrak 
baku (standard form Contract) mengacu pada perjanjian yang bentuknya sudah tercetak (printed, bolier plate) yang digunakan untuk berbagai kontrak yang sama atau sejenis (Treitel, 1999).

Slawson dalam tulisannya "Standardd Form Contract and Democratic of Law Making Power" sebagaimana dikutip oleh Pohan dalam Ery (Priyono, 2015).....menulis ...Standard contract form probably account for more than 90 percent of all contracts now made. Most persons have difficult remembering the last time they contracted other than by standardd form.Pernyataan ini menjadi pembenar maraknya perjanjian baku atau perjanjian standar, perjanjian adhesi dalam kehidupan bisnis sehari-hari yang cenderung disalah gunakan (HS, 2016).

Perjanjian bisnis "sebuah waralaba asing", yang menjadi obyek kajian dalam penelitian yang mendasari penulisan artikel ini adalah contoh sebuah perjanjian baku yang berlaku dalam dunia bisnis internasional. Sifat yang melekat pada perjanjian baku adalah "given" dalam artian pihak yang posisi tawar/ekonominya lebih tinggi/kuat menjadi penentu sekaligus pencipta/pembuat perjanjian. Pihak yang posisi tawar/ekonominya lebih rendah/lemah tidak mempunyai kesempatan untuk berkontribusi dalam pembentukan perjanjian. Dalam dunia praktek bisnis, perjanjian yang demikian ini sering disebut sebagai "take it or leave it contract" untuk menggambarkan ketidak berdayaan pihak yang lemah dalam menentukan isi perjanjian (Khairandy, 2013).

Patut diduga sifat perjanjian yang berbentuk baku/standar ini tidak akan mampu memberikan rasa keadilan yang memadai bagi pihak yang posisinya lemah. Keadilan dalam hal ini adalah keadilan yang didasari Asas Proporsionalitas, di mana para pihak mempunyai beban kewajiban dan hak yang proporsional dengan kontribusinya. (Hernoko \& Ratnawati, 2015).

Kenyataanya bentuk maupun isi perjanjian telah ditentukan oleh pihak yang kuat sebelum perjanjian itu ditandatangani oleh para pihak. Tidak akan bisa dipungkiri pihak yang kuat akan berusaha agar semua kepentingannya dapat diakomodir di dalam perjanjian tersebut, meskipun hal tersebut potensial untuk menimbulkan kerugian ekonomi pada pihak lainnya (Elliott \& Quinn, 2009).

Hakekat perjanjian atau kontrak termasuk perjanjian atau kontrak waralaba adalah suatu kesepakatan yang didasarkan pada kehendak sukarela, untuk mencapai suatu tujuan yang menguntungkan (economic prospective) yang dirasa adil bagi para pihak. Sebuah kontrak atau perjanjian tidaklah lahir karena kesepakatan semata tetapi juga harus memenuhi ketentuan hukum tentang syarat sah perjanjian sebagaimana diatur dalam Pasal $1320 \mathrm{KUH}$ Perdata, dengan kata lain perjanjian apapun nama baupun bentuknya tidak bisa mengabaikan 
aturan hukum yang berlaku di mana perjanjian itu dibuat dengan semata-mata mengandalkan pada kesepakatan yang didasari pada asas kebebasan berkontrak (Echenberg, 2011).

Indira Hastuti dalam artikelnya yang berjudul "Aspek Hukum Perjanjian Waralaba (Franchise), melihat waralaba sebagai bentuk usaha kemitraan yang belum diatur secara khusus yang dalam prakteknya didasarkan pada asas kebebasan berkontrak (Hastuti, 2006).

Asas kebebasan Berkontrak sebagai dasar pembentukan perjanjian waralaba, sering menjadi sebab terjadinya penyimpangan dalam perumusan hak dan kewajiban oleh pihak yang kuat, sehingga merugian pihak yang lemah (Priyono, 2015). Perlunya filter untuk mencegah ekses negatif perjanjian yang berbentuk baku dengan dalih penerapan Asas Kebeasan Berkontrak mendorong diterapkan Asas itikad baik dan Kepatutan (Priyono, 2016).

Bentuk perlindungan hukum yang lebih spesifik yang diberikan oleh negara adalah adanya PP no 16 tahun 1997 tentang Waralaba (yang kemudian diganti dengan PP no 42 tahun 2007) (Malik, 2007).

Pertanyaanya adalah, mengapa perjanjian atau kontrak waralaba yang secara legal formal telah memenuhi syarat sah perjanjian, dan juga disepakati bersama, ternyata dalam pelaksanaannya belum mampu memberikan rasa keadilan bagi para pihak khususnya pihak penerima waralaba (franchisee)?

Metode pendekatan dalam penelitian ini adalah yuridis normatif atau disebut juga metode doktriner. Spesifikasi penelitian ini menggunakan spesifikasi penelitian secara deskriptif analitis, maksudnya, yaitu peneliti dalam menganalisis permaslahan dengan cara memberikan gambaran secarfa faktual dikaitkan dengan norma hukum yang terkait.

Penelitian hukum ini menggunakan data sekunder yang berupa bahan hukum khususnya bahan hukum primer (Hadikusuma, 1995). Metode pengumpulan data didasarkan pada sumber data yang diperoleh dalam penelitian ini, data dikumpulkan dengan cara studi kepustakaan (library research) (Nazir, 2005). Sebagai cara untuk menarik kesimpulan dari hasil penelitian yang sudah terkumpul, akan dipergunakan metode analisis normatif-kualitatif, yang menitik beratkan pada aspek filosofis (keadilan) dengan model penyimpulan secara deduksi.

\section{B. PEMBAHASAN}

\section{a. Anatomi perjanjian waralaba "sebuah waralaba asing"}

Perjanjian ini dibuat dan ditandatangani pada tanggal 1 Mei 1989 antara "sebuah waralaba asing", yaitu perusahaan waralaba yang berpusat di di Kansas Amerika Serikat (USA) dengan PT. Sari Kencana sebuah perusahan berdasarkan hukum Indonesia yang berpusat di Jakarta. Recital/witnesseth perjanjian ini 
menjelaskan bahwa "sebuah waralaba asing" adalah perusahaan yang memiliki sistem restoran yang khas baik dari sisi pemasaran (dine ini and take away restourant), persiapan, penyajian dan penjualan pizza, pasta baik model Itali atau lainnya. Perusahaan ini juga telah mengembangkan dan mengadopsi sistem operasi bagi perusahaan dan para investornya yang unik yang meliputi; disain, iklan, perangakat disain, rahasia dagang, formula, teknis bisnis, sistem dan prosedur. Recital ini juga menjelaskan perusahaan adalah pemilik valuable goodwill, valuable mark, berkaitan dengan service mark, trade names, slogans, design, insignias, emblems, symbols, disain kemasan, disain bangunan yang khas, dll.

Perjanjian yang diberi judul perjanjian waralaba "sebuah waralaba asing" ini terdiri dari 26 pasal, dengan beberapa sub pasal. Sebagaimana lazimnya sebuah perjanjian waralaba, perjanjian ini berisi hal-hal seperti: Hak Kekayaan Intelektual (intellectual property Rights/IPR); IP transfer; royalty payment; kewajiban pajak; hak dan kewajiban para pihak, pengalihan dan atau lisensi hak kekayaan intektual; hukum yang mengatur; penyelesaian sengketa; dan terminasi perjanjian waralaba (Ryder, 2005). Henry R Cheesman, menyatakan secara umum ketentuan dalam perjanjian waralaba berisi : quality control sandards; training requirements; covenant not to compete; arbitration clauses; other terms and conditions, sebagai telah disebut di atas (Cheeseman, 2005).

Sebagaimana lazimnya perjanjian baku perjanjian ini dibuat oleh salah satu pihak yang kuat dalam hal ini adalah "sebuah waralaba asing" yang berpusat di Kansas Amerika Serikat (USA). "sebuah waralaba asing" adalah satu satunya pihak yang menentukan isi maupun bentuk perjanjian, sementara PT Sarimelati hanya bisa tanda tangan jika setuju terhadap isi perjanjian tanpa bisa merubahnya dan tidak tanda tangan jika tidak setuju dengan isi perjanjian.Perjanjian yang terdiri dari 27 pasal ini berisi 80 kewajiban bagi penerima waralaba (franchisee) dan haknya tidak lebih dari 20. Secara bertimbal balik maka pemberi waralaba mempunyai hak terhadap penerima waralaba sebanyak 80 dan kewajibannya kurang dari 20. Suatu potret perjanjian yang tidak menjamin keseimbangan, keadilan (Priyono, 2009).

\section{b. Proses terjadinya perjanjian}

Perjanjian dilihat dari proses pembentukannya dapat dibedakan menjadi tiga tahap; yaitu tahap pra kontrak; kontrak dan pasca kontrak(Khairandy,2013). Pra Kontrak merupakan tahapan yang sangat penting dalam rangkaian perjanjian, karena pada tahap itu terjadi proses permufakatan (negosiasi) yang lazim disebut dengan penawaran (offer) dan penerimaan (acceptance) yang berujung pada dua kemungkinan, sepakat atau tidak sepakat (Turner, 2007). 
Kebebasan berkontrak adalah asas yang esensial, baik bagi individu dalam mengembangkan diri baik di dalam kehidupan pribadi maupun kehidupan sosial ke masyarakatan, sehingga beberapa pakar menegaskan kebebasan berkontrak merupakan bagian dari hak asasi manusia yang harus dihormati (Khairandy,2013).

Negara-negara yang mempunyai system hukum Common Law mengenal kekebasan berkontrak dengan istilah Freedom of Contract atau laisseiz faire. Jessel M. R. merumuskan dalam kasus "Printing and Numerical Registering Co. Vs Samson" (Rusli, 1993) .....men of full age and understanding shall have the utmost liberty of contracting, and that contracts which are freely and voluntarily entered into shall be held sacred and on force by the courts.....you are not lightly to interfere with this freedom of contract.

Asas kebebasan berkontrak (partij autonomie, freedom of contract), menjadi sumber berkembang pesatnya hukum perjanjian, tidak hanya di Indonesia, begitu juga di tingkat regional maupun internasional (Coson \& Mazeaud). Seperti di Jepang (Hooft, 2005), China (Zhang, 2006), dan India (Bath, 2009).

Berdasarkan asas kebebasan berkontrak, maka orang-orang boleh membuat atau tidak membuat perjanjian. Para pihak yang telah sepakat akan membuat perjanjian bebas menentukan apa yang boleh dan tidak boleh dicantumkan dalam suatu perjanjian (Racine, 2008).

Kesepakatan yang diambil oleh para pihak mengikat mereka sebagai undang-undang. (Pasal 1338 KUH Perdata). Penerapan asas ini memberikan tempat yang penting bagi berlakunya asas konsensual, yang mengindikasikan adanya keseimbangan kepentingan, kesembingan dalam pembagian beban resiko, dan keseimbangan posisi tawar (bargaining position) (Racine, 2008).

Perkembangannya dalam praktek apa yang mengikat sebagai undang-undang bagi para pihak itu didasarkan kesepakatan semu.

Dalam perkembangannya asas ini muncul menjadi paradigma baru dalam hukum kontrak yang menjurus pada kebebasan tanpa batas (unretristicted freedom of contract). Kondisi sekarang, asas ini juga membuat orang/pihak yang kuat bisa memaksakan kehendaknya terhadap pihak yang lemah, sehingga cita-cita kebebasan berkontrak yang awalnya memberikan keseimbangan hukum, keseimbangan kepentingan dan juga keseimbangan dalam posisi tawar, menjadi sarana penekan bagi pihak yang lemah, oleh karena itu Pasal 1337 KUH Perdata memberikan batasan pada praktek penerapan asas tersebut dengan menegaskan "sebab" perjanjian itu harus halal artinya tidak dilarang undang-undang, tidak bertentangan dengan kesusilaan yang baik atau ketertiban umum Perjanjian waralaba "sebuah waralaba asing" yang terdiri dari 26 pasal , jika dilihat dari 
Jurnal Law Reform

Volume 14, Nomor 1, Tahun 2018
Program Studi Magister Ilmu Hukum Fakultas Hukum Universitas Diponegoro keseluruhan pasal tersebut ternyata isinya 24 pasal selalu mencantumkan hal-hal yang bersifat tanggung jawab/kewajiban yang harus dipenuhi oleh operator/franchisee. Hanya 2 pasal yang tidak secara langsung menetapkan keawjiban bagi operator, yaitu pasal XX tentang notices dan pasal XXI tentang interpretasi, pelaksanaan perjanjian, dan pelepasan hak.

Isi perjanjian yang tertulis dalam 26 pasal perjanjian tersebut menurut penulis bukan cerminan hasil kesepakatan. Bagaimana tidak dikatakan demikian jika perjanjian yang terdiri dari 26 pasal itu memuat kewajiban bagi investor/operator/franchisee yang jumlahnya lebih dari 80 kewajiban, pada saat yang sama kita ketahui hak principal/franchisor lebih dari 80, suatu kondisi yang sangat tidak seimbang. Bahkan jika kita mengikuti pendapat Untung Felix S Soebagjo yang menyatakan .."dianggap ada kesepakatan ketika kepentingan para pihak dapat dilaksanakan secara seimbang" (Soebagjo, 1993). Perjanjian ini memberikan gambaran kepada kita bahwa posisi company / franchisor / principal yang begitu dominan secara ekonomi menjadi penentu bagi pihaknya untuk menetapkan "undang-undang" bisnis yang mengikat secara ketat siapaun yang ingin bekerjasama dengannya. Jadi tidaklah berlebihan jika sebagian ahli yang berpendapat tidak setuju dengan penggunaan perjanjian baku karena mereka tidak ubahnya "pembuat undang-undang swasta (Treitel, 1999).
Pasal 1338 alinea 3 KUH Perdata : perjanjian harus dilaksanakan dengan itikad baik (Black, 2017). Itikad baik (good faith) dalam Black's Law Dictionary didifinisikan sebagai..... is an intangible and abstract quality with no technical meaning or statutory definition, and it encompasses, among other things, an honest belief, the absence of malice and the absence of design to ddefraud or to seek an unconscionable advantage, and an individual's personal good faith is concept of his own mind and inner spirit and, therefore, may not conclusively be determined by his protestations alone.

Perkembangan selanjutnya campur tangan pemerintah menjadi lebih besar karena tuntutan perlindungan kepada masyarakat atau konsumen atau pelaku bisnis nasional. Sehingga sebuah bisnis waralaba yang sepenuhnya tunduk pada ketentuan hukum perjanjian yang bersifat privat pada perkembangannya tidak bisa menyimpangi bebrapa aturan yang bersifat publik, misalnya ketentuan pendaftaran perusahaan waralaba

Peraturan Pemerintah (PP) tentang Waralaba No. 42 Tahun 2007 yang berlaku efektif mulai tanggal 24 Juli 2008. Pewaralaba (pemberi waralaba :franchisor) wajib mendaftarkan prospektus penawaran waralaba, dan terwaralaba (penerima waralaba : franchisee) harus mendaftarkan perjanjian waralaba. 


\section{c. Kesepakatan yang tidak berbuah keadilan}

Asas ini memberikan informasi bahwa suatu perjanjian pada dasarnya sudah ada sejak tercapainya kata sepakat diantara para pihak dalam perjanjian tersebut. Asas konsensualisme yang terdapat dalam Pasal 1320 KUHPerdata mengandung arti kemauan para pihak untuk saling mengikatkan diri dan kemauan ini membangkitkan kepercayaan bahwa perjanjian itu akan dipenuhi.

Eggens dalam Ibrahim (Ibrahim, 2003) menyatakan ,asas konsensualitasmerupakan suatu puncak peningkatan manusia yang tersirat dalam pepatah ; een man een man, een word een word. Selanjutnya dikatakan olehnya bahwa ungkapan "orang harus dapat dipegang ucapannya " merupakan tuntutan kesusilaan, akan tetapi Pasal 1320 KUH Perdata menjadi landasan hukum untuk penegakannya. Tidak dipenuhinya syarat konsensualisme dalam perjanjian menyebabkab perjanjian dapat dibatalkan, karena tidak memenuhi syarat subyektif.

Asas ini berkaitan dengan lahirnya suatu perjanjian. Konsesualisme mengandung arti bahwa perjanjian itu terjadi karena adanya kata sepakat atau kehendak yang bebas dari para pihak yang membuat perjanjian mengenai isi atau pokok perjanjian.

Pasal 1338 ayat (1) KUH Perdata menyebitkan bahwa : "Semua perjanjian yang dibuat secara sah berlaku sebagai undangundang bagi mereka yang membuatnya". Di dalam pasal tersebut dijumpai asas Konsensualisme yang terdapat pada kata "... perjanjian yang dibuat secara sah...", yang menunjuk pada Pasal 1320 KUH Perdata, terutama pada ayat 1 yaitu mereka sepakat mengikatkan dirinya.

Dokumen perjanjian yang telah ditanda tangani para pihak ini, merupakan perjanjian baku yang telah disiapkan oleh pihak yang lebih kuat, yaitu company/franchisor maka dapat dipastikan isinya telah dirancang oleh pihak dan untuk keuntungan franchisor. Perjanjian yang mempunyai sifat baku tidak memberi peluang yang cukup bagi pihak yang lebih lemah untuk mengekspresikan kebebasan yang didasarkan asas kebebasan berkontrak guna melindungi kepentingannya sebagai pihak dalam perjanjian.

Bersasarkan pasal-pasal yang ada, dapat dilihat kebebasan untuk tercapainya kesepakatan tidak terjadi dengan berimbang, karena dominasi comany/calon franchisor terhadap calon franchisee. Pada pasal yang mengatur hak dan kwajiban terlihat kepentingan franchisor lebih mendapat perlindungan hokum dibanding dengan kepentingan franchisee.

Sebagai salah satu contoh adalah pasal yang mengatur tentang uang deposit (non refundable territorial franchise fee: yaitu sejumlah uang yang harus disetor oleh franchisee sebesar 100000 U.S. \$ yang tidak bisa ditarik kembali. 
Pembayaran diangsur $2 \times$ setelah perjanjian ditanda tangani oleh para pihak.

Rumusan Pasal 15 (XV) tentang default and Termination dan Pasal 16 tentang right and Obligation terkait terminasi , jika dicermati, maka rumusan ini sangat tidak adil karena bisa jadi tidak terpenuhinya kewajiban franchisee terhadap franchisor disebabkan oleh kesalahan/kelalaian pihak franchisor sendiri, sehingga segala kerugian yang timbul semestinya ditanggung bersama.

Pasal lain yang dapat menjadi bukti asas konsensual tidak berjalan seimbang tetapi berjalan sesuai kehendak franchisor adalah pasal-pasal yang mengatur larangan-larangan bagi franchisee baik pada waktu perjanjian masih berlangsung atau setelah berakhir (bandingkan Article XVI perjanjian waralaba "sebuah waralaba asing") : Rights and Obligations of Parties on Termination or Expiration) dalam pasal tersebut dirumuskan .....operator (franchisee) shall immediately discontinue, atau operator (franchisee) obliges......sementara untuk rumusan franchisor .......Company has right... .

Berikut adalah larangan-larangan itu yang antara lain berbunyi.....setelah berkahirnya perjanjian maka franchisee untuk beberapa tahun dilarang; (1)Langsung maupun tidak langsung terikat dengan usaha yang sama (dengan cara dan gaya yang sama atau memiliki kemiripan dengan sistem, merek dagang, atau nama produk yang serupa ), (2) Langsung atau tidak langsung terlibat dalam pelaksanaan bisnis yang menawarakan barang dan jasa yang serupa yang berkompetisi dengan bisnis, (3) Untuk kepentingan sendiri menjalankan, baik sendiri maupun dengan mitra bisnisnya atau terlibat dengan perusahaan yang bisnisnya berkompetisi dengan usaha tersebut, (4) Membajak, mencampur tangan atau mempekerjakan staff eksekutif dari pemberi hak waralaba atau dari pewaralaba lain milik pemberi hak waralaba, (5) Membantu perorangan, perusahaan atau pihak ketiga dengan konsultasi teknis dalam hubungannya dengan bisnis yang bersaing dengan usaha terkait, langsung maupun tidak langsung, pada bisnis yang berkompetisi dengan bisnisnya franchisor.

Fakta menunjukkan perjanjian yang dibuat oleh salah satu pihak yang biasanya dalam format baku cenderung mnimbulkan kerugian pada salah satu pihak, dan sebaliknya menguntungkan pihak yang lain. Di dalam kepustakaan hukum Inggris untuk istilah perjanjian baku digunakan istilah standardized agreement atau standardized contract (Ibrahim, 2003).

Sutan Remy Sjahdeini merumuskan perjanjian baku adalah perjanjian yang hampir seluruh klausula - klausulanya sudah dibakukan oleh pemakainya dan pihak yang lain pada dasarnya tidak mempunyai peluang untuk merundingkan atau meminta perubahan (Priyono, 2017). 
Sutan Remy Sjahdeini berpendapat bahwa keabsahan berlakunya perjanjian baku tidak lagi dipersoalkan oleh karena perjanjian baku eksistensinya sudah merupakan kenyataan yaitu dengan telah dipakainya perjanjian baku secara meluas dalam dunia bisnis sejak lebih dari 80 tahun lamanya. Kenyataan itu terbentuk karena perjanjian baku memang lahir dari kebutuhan masyarakat sendiri. Dunia bisnis tidak dapat berlangsung tanpa perjanjian baku. Perjanjian baku dibutuhkan oleh dan karena itu diterima oleh masyarakat.

Stephen Simister dan Rodney Turner menyatakan dalam karya tulisnya... Standard forms of contract purport to provide a representative viewpoint of the industry which they serve. Rather than favour one particular party to the contract, standard forms should represent both parties on an equal and fair basis by providing for an equitable distribution of risk (Priyono, 2017).

Keabsahan berlakunya perjanjian baku memang tidak perlu dipersoalkan, tetapi masih perlu dibahas apakah perjanjian itu tidak bersifat sangat berat sebelah dan tidak mengandung klausul yang secara tidak wajar sangat memberatkan bagi pihak lainnya, sehingga perjanjian itu merupakan perjanjian yang menindas dan tidak adil.

Sehubungan dengan penetapan isi secara sepihak, Sluyter dalam Hasanuddin Rahman mengatakan bahwa secara materiil, perjanjian ini melahirkan "legio particuliere wetgevers" (pembentuk undang-undang swasta). Dalam pada itu, Stein dalam Hasanuddin Rahman mengemukakan pula bahwa dasar berlakunya perjanjian ini adalah berdasarkan fiksi hukum (de fictie van will vertrouwen) (Priyono, 2009). Secara formil debitur menyetujuinya, namun secara materiil debitur "terpaksa" menerimanya. Adanya persesuaian kehendak adalah fiktif.

Perjanjian yang bentuknya baku, dengan pasal-pasal yang sudah dibakukan cenderung menguntungkan salah satu pihak yang pada sisi lainnya merugikan pihak lainnya. Perjanjian baku yang dibuat oleh satu pihak ini sering menjadi sarana untuk menyalah gunakan keadaan ( undue influence) yang diancam dengan kebatalan perjanjian (Stone, 2011). Bahkan bisa juga batal demi hukum.

Asas kebebasan berkontrak sebagaimana dapat disimpulkan dari Pasal 1338 ayat (1) KUH Perdata yang mempunyai hubungan erat dengan Pasal 1320 KUH Perdata yang mengatur mengenai asas konsensualisme yang menjadi salah satu syarat syahnya suatu perjanjian kemungkinan besar dilanggar dengan adanya perjanjian baku tersebut. Perjanjian waralaba "sebuah waralaba asing" adalah perjanjian baku dengan mencantumkan beberapa syarat yang bersifat eksoneratif, oleh karena itu perlu dibuat aturan yang tegas dan dilaksanakan dengan tegas tentang larangan syarat baku yang 
eksoneratif ini demi untuk melindungi pertumbuhan usaha nasional yang kompetitif.

Hukum harus adil, begitu kata Gustav Radbruch)..... famously argued that a sufficiently unjust rule loses its status as a valid legal norm (Bix, 2011). Peraturan hukum positif sebagai bagian dari hukumpun harus mencerminkan hal tersebut, keadilan adalah rohnya hukum. Selain itu, sebagai bukti "negara hadir" maka hukum positif yang tercipta juga harus mampu memberikan kemanfaatan yang semaksimal mungkin bagi rakyatnya. Seburuk apapun peraturan hukum positif yang dibuat oleh pemerintah (flawed law) tetap harus bisa menghasilkan keadilan (Bix, 2011).

Perjanjian waralaba tidak semata-mata tunduk pada prisip-prinsip dan aturan-aturan hukum perjanjian yang bersifat privat, tetapi juga harus memperhatikan aturan hukum yang bersifat hukum publik, yang bersifat mandatory rules, bahkan guna memberikan rasa adil bagi para pihak maka kedepan aturan hukum positif yang mengatur waralaba tidak hanya tunduk pada hukum publik yang bersifat wajib, tetapi juga hukum hukum yang berkembang diluar sistem hukum yang berlaku di Indoensia seperti, pinsipprinsip hukum islam, new lex mercatoria, CISG dill.

\section{c. KESIMPULAN}

1. Asas kebebasan berkontrak (Pasal 1338: 1 KUH Perdata) yang menjadi dasar lahirnya perjanjian waralaba "sebuah waralaba asing" di Indonesia perlu diikuti dengan seperangkat aturan hukum yang mengikat para pihak yang memberikan perlindungan hukum secara lebih proporsional bagi para pihak.

2. Asas konsensualisme yang terdapat dalam pasal 1320 KUHPerdata mengandung arti kemauan para pihak untuk saling mengikatkan diri dan kemauan ini membangkitkan kepercayaan bahwa perjanjian itu akan dipenuhi. Hal ini menjadi sulit terwujud ketika salah satu pihak mempunyai posisi tawar yang jauh lebih kuat dibanding pihak lainnya

3. Perjanjian yang bersifat baku pada dasarnya tidak dilarang sepanjang di dalamnya tidak memuat pasal-pasal yang bersifat eksoneratif. Pasal- pasal yang eksoneratif telah melanggar ketentuan syarat sah perjanjian ,Pasal $1320 \mathrm{KUH}$ Perdata yang berakibat batal demi hukum atau dapat dibatalkannya perjanjian.

\section{DAFTAR PUSTAKA}

\section{BUKU:}

Schwartz, Alan \& Scott, Robert E. (2003). Contract Theory and the Limits of Contract Law. Virginia : Yale law Schools Publishing

Corbin, A. (1919) Conditions in the Law of Contract. Virginia : Yale law Schools Publishing 
Coson, Benedicte Fauvarque. and Mazeaud, Denis. editors, (2008) European Contract Law. Munich : European Law Publisher.

Elliott, Catherine \&, Quinn, Frances (2009). Contract Law, Seventh Edition. New York: Library of Congress Cataloging-inPublication Data.

Echenberg, D. (2011). Negotiating international contracts: does the process invite a review of standard contracts from the point of view of national legal requirements, London: Cambridge University Press.

Supramono, G. (2009). Perbankan dan Masalah Kredit Suatu Tinjauan di Bidang Yuridis, Jakarta : Rineka Cipta.

Giuditta Cordero-Moss (editor).(2011). Boilerplate Clauses International Commercial Contracts and The Applicable Law, London : Cambridge Universiry Press.

Cheeseman, Henry R. (2000). Contemporary Business Law, Third edition, New Yersey : Prentice Hall, Upper Sadler River

Hadikusuma, H. (1995). Metode Pembuatan Kertas Kerja atau Skripsi Ilmu Hukum. Bandung : Mandar Maju.

Zhang, M. (2006). Chinese Contract Law, Leiden, Boston : Martinus Nijhoof Publisher.

Nazir, M. (2005). Metode Penelitian. Jakarta : Ghalia Indonesia.

Fuady, M. (2014). Konsep Hukum Perdata, Bandung ; Rajawali Press.
Fuady, M. (1994). Hukum Bisnis dalam Teori dan Praktek Buku Kedua. Bandung : Citra Aditya Bakti.

Fuady, M. (1999). Hukum Perbankan Modern. Bandung : Citra Aditya Bakti.

Richard A. Epstein, Contracts Small and Contract Large: Contract Law Through the Lens of Laissez-Faire, prepared for a conference on The Doctrine of Contract and Modern Social Policy, sponsored by the Donner Foundation, and organized by the Law and Economics Center of George Mason University Law School, held on November 15 and 161996.

Stone, R. (2002). The Modern Law of Contract, Fifth edition, London : Cavendish Publishing Limited

Stone, R. (2011). The Modern Law of Contract, ninth, London : Taylor and Francis Group.

Khairandy, R. (2003). Itikad baik dalam kebebasan berkontrak. Jakarta : Pasca sarjana Fakultas Hukum UI.

Khairandy, R. (2013). Hukum Kontrak Indonesia dalam Perspektif Perbandingan. Yogyakarta : FH UII Press.

Ryder, Rodney D (2005). Corporate, and CommercialAgreements, Drafting Guidelines, Form and Precedents. New Delhi : Universal Law Publishing CO. PVT.LTD 
Bath, S. (2009). Basis For Cntract Law dalam Law and Business Contracts in India. India : Saiga Publications.

Sepe, S.M. (2010). Good Faith And Contract Interpretation: A Law And Economics Perspective Arizona: James E Roger College of law Publishing

Soebagjo, Untung Felix S (1993). Perkembangan asas-asas Hukum Kontrak dalam Praktek Bisnis selama 25 tahun terakhir. Pelatihan Hukum Perjanjian UGM Jogjakatra

Hooft, Willem M Vissert. (2005). Japanese Contract and Anti trust Law. London : Routledge Curzon Taylor \&Francis Group.

Simamora, Y. Yogar. (2013). Hukum Kontrak, Kontrak Pengadaan Barang dan Jasa Pemerintah di Indonesia, Surabaya : Penerbit Kantor Hukum Wins \& Partners. Zoha Sirhindi, Esq. (2010) The Law of Contract. London, New York : Baar accociation Publisher

\section{JURNAL:}

Hernoko, A Yudha \& Ratnawati, Ika Yunia. (2015) Asas Proporsionalitas dalam Perjanjian Waralaba (Franchise). Jurnal Hukum Bisnis, Vol. 1 (No.1, April), pp. 1-17

Bix, B.H. (2011). Radbruch's Formula and Conceptual Analysis. American Journal J urisprudence, Vol. 56, p.46.
Malik, C. (2007) Implikasi Hukum Adanya Globalisasi Bisnis Franchise, Jurnal Hukum UII. Vol.14 (No.1,Januari), pp. 97113

Priyono, E.A. (2015). Penerapan Asas Kebebasan Berkontrak dalam pembuatan Perjanjian Franchise Es Teler 77 (suatu pendekatan normatif). J urnal FH Undip, Masalah-Masalah Hukum. Vol.44 (No.2, April), pp. 123-129

Priyono, E.A. (2016). Penerapan Asas Itikad Baik dan Kepatutan dalam Perjanjian Waralaba. J urnal Hukum USM HUMANI. Vol.6 (No. 3, September). pp. 65-75

Priyono, E.A. (2017). Peranan Asas Itikad Baik dalam Kontrak Baku. Diponegoro Private Law Review J urnal Bag. Keperdataan FH Undip. Jilid 1 (No.1, November). pp.13-21 Ilhamdi. (2014). Perjanjian Kerjasama Waralaba antara PT. Raos Aneka Pangan dengan Ny. Hj. Maryenik Yanda. J OM, J urnal FH Riau Vol. 1 (No. 2 Oktober). pp. 1-15 Hastuti, I. (2006). Jurnal Hukum dan Dinamika, Edisi Oktober. pp. 27-38

Idrus, N.S. (2017). Aspek Hukum Perjanjian Waralaba dalam Perspektif Hukum Perdata dan Hukum Islam. Yuridis, Jurnal FH UPN, Vol.4 (No.1, Juni). pp. 28-45

\section{LAPORAN PENELITIAN :}

Ery Agus Priyono, Laporan Penelitian FH Undip tahun 2012 : Klausula-klausula dalam 
Jurnal Law Reform

Volume 14, Nomor 1, Tahun 2018
Program Studi Magister Ilmu Hukum Fakultas Hukum Universitas Diponegoro

Kontrak Alih Teknologi yang Potensial

Merugikan Perekonomian Indonesia

ditinjau dari Penerapan Asas-asas dalam

Pembuatan dan Pelaksanaan Perjanjian

(Pembuatan Model Perjanjian Lisensi -

Alih Teknologi yang Berkeadilan yang

Mendukung Pertumbuhan Perekonomian

Indonesia)

Ery Agus Priyono, Penerapan Asas Kebebasan

Berkontrak dalam Perjanjian waralaba

(suatu Kajian Normatif pada Perjanjian

Waralaba Indomaret), Laporan Penelitian

. Semarang, November 2014

Ery Agus Priyono, Penerapan Asas Kebebasan

Berkontrak dalam Pembuatan Perjanjian

yang dibuat secara Baku, Laporan

Penelitian, Program Magister

Kenotariatan, 2009. 